\title{
German science fights animal rights bill
}

[MUNICH] Proposals to modify Germany's constitution to include a provision protecting the rights of animals have come under fire from the country's main research agencies, as well as pharmaceutical and chemical companies.

The change is being proposed by the governing coalition of Social Democrat and Green parties. The addition would state that animals have the right to be "respected as fellow creatures" who have an individual right to be protected from "avoidable pain".

Similar changes have also been proposed by two opposition parties: the Free Democrat Party and the reformed East German Communist Party.

Vocal resistance to the change has come from the research community, with opposition expressed by Germany's largest research council, the Deutsche Forschungsgemeinschaft (DFG), the Max Planck Society, the Conference of University Rectors, and the Conference of Mathematical and Scientific Faculties. They argue that it would damage biomedical research - a position supported by the Association of the Chemical Industry, and the pharmaceutical company BASF.

In a statement, the DFG questioned the need to change the constitution, saying that Germany's animal rights legislation is among the strictest in Europe. They also claimed that such a provision would conflict with the constitutional protection of research freedom.
"If animal rights become a constitutional issue then the scope for legal challenges to experiments could be immense," says Hubert Markl, president of the Max Planck Society. This could result in approval procedures being delayed for "months or even years", he claims. "Scientists in highly competitive fields would either change the direction of their research or move elsewhere."

The Conference of University Rectors warned that constitutional protection of animal rights risks legitimizing and encouraging the activities of militant groups opposed to animal research (see Nature 396, 505; 1998). And one observer argues that in practice such a measure would do little to alleviate animal suffering through intensive farming and long-distance livestock transport.

At a first reading in the Bundestag, Germany's federal parliament, last month, the moves were challenged by speakers from the main opposition party, the Christian Democrats (CDU), who backed scientists' arguments that such a change could damage the country's biomedical research base.

Without support from the Christian Democrats, this constitutional change is unlikely to obtain the two-thirds majority vote required at the final second hearing.

A question mark also hangs over the support for the proposal within the Social Democrat party itself. The chancellor, Gerhard Schröder, has expressed commitment

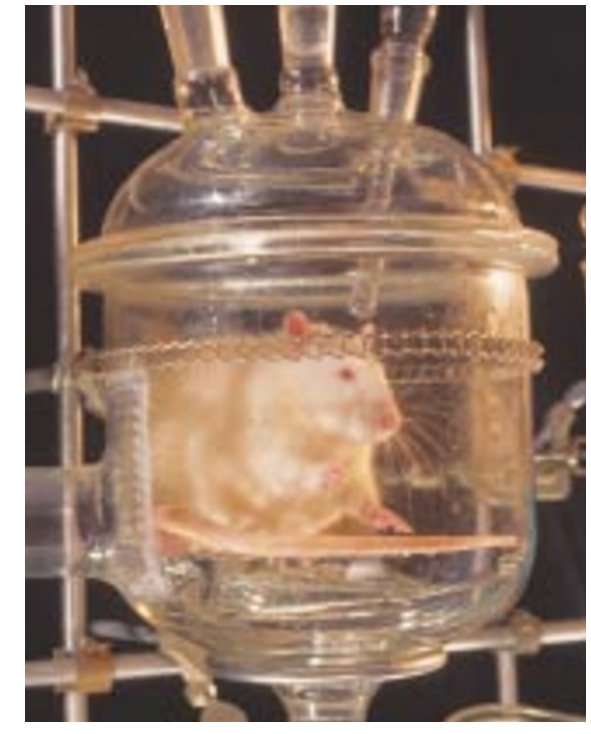

Laboratory life: Germany proposes to give animals constitutional rights as individuals.

to such a change, but observers point out that this was before the party came to power, and that a unanimous 'yes' vote from Social Democrats is unlikely.

In a bid to attract support within the party and from the Christian Democrats, the government is considering a watered-down proposal which would affirm the need to protect animals, but would stop short of giving rights to individual animals.

Quirin Schiermeier

\section{Japanese univers ity approves genetic tests on in vitro embryos}

[токуо] The first clinical application of preimplantation genetic diagnosis in Japan moved a step closer last week with the approval by the ethics panel of Kagoshima University Medical School of a protocol for testing for Duchenne muscular dystrophy in human eggs fertilized in vitro.

A decision on whether to go ahead depends on the approval being confirmed by the Japan Society of Obstetrics and Gynaecology. The society last year opened the way to preimplantation genetic diagnosis in principle when it approved general guidelines covering such procedures (see Nature 394, 110; 1998). These allow couples to ask for eggs used for in vitro fertilization to be discarded if susceptibility to certain types of hereditary disorder is detected in the genes.

But the society came under fire, as its guidelines were seen as a poor replacement for a national debate on the ethical issues. Critics argued that legislation was needed to prevent such techniques being put to nonmedical uses, such as selecting the sex of a child.

Akira Hira, principal of the university's medical school and chairman of the ethics committee, says its decision was based on the safety and reliability of the technique, and the potential benefit it would bring to patients. But he admits that gaining public acceptance will not be easy. "There are still a lot of ethical and scientific questions we would have to explain to the public to gain their support and understanding," he says.

Concern about the ethical implications of Kagoshima University's move has been voiced by the anti-eugenics patients' advocacy group, which represents more than 30 womens' and disabled groups. They argue that prenatal diagnosis risks increasing discrimination against the disabled.

But Hiroyuki Nagata, professor of reproductive medicine at Kagoshima University, argues that early detection of genetic disorders would allow mothers undergoing in vitro fertilization to avoid 'therapeutic abortions'.

The approved protocol involves a couple who already have a child suffering from Duchenne muscular dystrophy. "I feel that the protocol poses fewer ethical problems than prenatal genetic diagnosis [of fetuses] and therapeutic abortion does," says Nagata.

The university originally approved the same protocol in 1995, but was forced to postpone a final decision because of opposition from patients' advocacy groups. Since then, the society has issued guidelines, and the latest proposals are based on them.

Opposition from patients' advocacy groups has similarly forced the Japan Society of Obstetrics and Gynaecology to postpone approval of specific guidelines for screening for Duchenne muscular dystrophy (see Nature 385, 763; 1997). The general guidelines approved last year do not specify which diseases can be tested for, but limit screening to serious diseases, and require case by case approval by a specialist committee of doctors and geneticists appointed by the society.

Keiko Yano, the director of the advocacy group, argues, however, that the ethical issues the technique raises require greater discussion before any further decision is made on the application of preimplantation genetic diagnosis.

Asako Saegusa 